\title{
AKTIVITAS ANTIDIABETES EKSTRAK ETANOL DAUN ASAM JAWA (Tamarindus Indica Linn) TERHADAP ENZIM ALFA GLUKOSIDASE
}

\author{
Hasmalina Nasution, Musyirna Rahmah Nst, Reza Abdifi
}

Universitas Muhamadiyah, Sekolah Tinggi Ilmu Farmasi Riau, Pekanbaru, Riau, Indonesia

\begin{abstract}
ABSTRAK
Secara empiris tanaman obat tradisional terbukti dapat menurunkan kadar glukosa darah. Salah satunya daun asam jawa (Tamarindus Indica Linn). Telah dilakukan pengujian penentuan aktivitas antidiabetes daun asam jawa terhadap enzim $\alpha$-glukosidase. Hasil skrining fitokimia ekstrak etanol daun asam jawa mengandung senyawa metabolit sekunder flavonoid, fenolik dan saponin. Pengujian aktivitas antidiabetes ekstrak etanol daun asam jawa terhadap enzim alfa glukosidase dilakukan dengan menggunakan metoda spektrofotometri. Pada konsentrasi 1000 ppm ekstrak etanol memiliki efek antidiabetes melalui penghambatan enzim $\alpha$-glukosidase sebesar 20,8\%. Efek antidiabetes daun asam jawa lebih kecil dibanding glukobay.
\end{abstract}

Kata kunci: antidiabetes, asam jawa, $\alpha$-glukosidase

\section{PENDAHULUAN}

Diabetes melitus adalah salah satu penyakit atau kelainan metabolisme yang paling sering dijumpai dalam masyarakat. Diabetes melitus ini merupakan penyakit degeneratif yaitu penyakit akibat fungsi atau struktur dari jaringan atau organ tubuh yang secara progresif menurun karena usia atau pengaruh gaya hidup. Penderita diabetes pada umumnya menjalani hiperglikemia.

Aktivitas antidiabetes dapat terjadi berdasarkan beberapa mekanisme yaitu dengan menstimulasi sel $\beta$-Langerhans untuk menghasilkan insulin dan penghambatan aktivitas enzim (Matsumoto, et al, 2002). $\alpha$-glukosidase bertanggungjawab dalam memecah karbohidrat menjadi glukosa pada usus halus manusia. Dengan penghambatan aktivitas enzim tersebut, dapat menunda pemecahan karbohidrat di usus dan menurunkan absorbsi gula darah. Oleh karena obat antidiabetes oral kebanyakan memberikan efek samping yang tidak diinginkan seperti kembung, diare, dan kejang perut, maka para ahli mengembangkan sistem pengobatan tradisional untuk diabetes melitus yang relatif aman (Lee, 2007: Modak, et al, 2007).

Makin populernya perilaku back to nature, pengobatan alternatif merupakan salah satu sumber pelayanan kesehatan yang mudah diperoleh dan terjangkau oleh masyarakat luas dan memiliki efek samping yang relatif kecil. Salah satu cara untuk mengatasi diabetes adalah dengan memanfaatkan potensi tanaman obat.

Salah satunya tanaman obat tradisional adalah daun asam jawa (Tamarindus Indica Linn). Secara empiris, menurut Soedibjo (1998), tumbuhan ini dimanfaatkan sebagai penurun gula darah dengan cara meminum air rebusan daun asam jawa. Secara invivo, ekstrak metanol biji asam jawa berkhasiat menurunkan gula darah tikus yang diinduksi streptozotosin (Diabetes melitus tipe 1) (Rachmander, et all, 2010 ). Akan tetapi belum ada penelitian yang melaporkan efek antidiabetes daun asam jawa melalui mekanisme penghambatan enzim alfa 
glukosidase. Oleh karena itu, penelitian ini bertujuan untuk mendapatkan data ilmiah aktivitas antidiabetes ekstrak etanol daun asam jawa terhadap enzim $\alpha$-glukosidase secara invitro.

\section{METODOLOGI PENELITIAN}

\section{Alat dan Bahan}

Alat-alat yang digunakan: alat destilasi, rotary evaporator, $\mathrm{pH}$ meter, microplate reader 96 wells, inkubator, timbangan analitik (Acculab), sentrifuse, vortex mixer (VM-2000), pipet mikro 10-100 $\mu 1$ dan 100$1000 \mu 1$ (Eppendorf), eppendrorf tube dan peralatan gelas yang biasa digunakan di laboratorium.

Bahan yang digunakan adalah aquadest, etanol, etil asetat, n-heksan, larutan buffer fosfat $\mathrm{pH} 7$ (Sigma-aldrich, USA), Bovin serum albumin (BSA) (Merck, jerman), enzim $\alpha$-glukosidase (Sigma-aldrich, USA), substrat p-nitrofenil- $\alpha$-D-glukopiranosa (Sigma-aldrich, USA), acarbose (Glucobay®), dimetilsulfoksida (Sigmaaldrich, USA), larutan $\mathrm{Na}_{2} \mathrm{CO} 3$ (Sigmaaldrich, USA).

\section{Pengambilan dan Identifikasi Sampel}

Sampel yang digunakan adalah daun asam jawa yang diambil di daerah Pekanbaru.

\section{Pembuatan Ekstrak, Fraksinasi sampel dan Uji Fitokimia}

Daun asam jawa segar dikumpulkan dan dicuci bersih, kemudian dikering anginkan, dirajang dan ditimbang. Lalu dimaserasi dengan menggunakan pelarut etanol hingga terendam dengan sempurna. Wadah ditutup rapat dan campuran disimpan di tempat yang terlindung dari cahaya selama 3-5 hari sambil diaduk berulang. Selanjutnya filtrat diambil melalui penyaringan dan ditambah kembali dengan pengekstrak ke dalam wadah sampel, maserasi dilakukan sebanyak tiga kali. Maserat yang didapat kemudian dikentalkan dengan rotary evaporator sampai didapat ekstrak kental. Kemudian ekstrak kental etanol tersebut di fraksinasi menggunakan pelarut n-heksan dan residunya difraksi dengan etil asetat. Hasil dari fraksinasi dipekatkan dengan rotary evaporator sehingga diperoleh ekstrak kental fraksi n-heksan dan etil asetat. Hasil dari masing-masing ekstrak ditimbang dan dilakukan uji fitokimia diantaraya uji senyawa saponin, fenolik, flavonoid, terpenoid, steroid dan alkaloid.

Uji inhibisi enzim a-glukosidase secara in vitro (Sancheti et al, 2009)

Pada microplat 96 well, $10 \mu \mathrm{L}$ ekstrak $1000 \mathrm{ppm}$ ditambah dengan $50 \mu \mathrm{l}$ buffer fosfat (pH 7), $25 \mu \mathrm{l} 20 \mathrm{mM}$ PNPG, $25 \mu \mathrm{l} \alpha$ glukosidase $(0,2 \mathrm{U} / \mathrm{ml})$ lalu inkubasi selama 30 menit pada suhu $37^{\circ} \mathrm{C}$. Setelah 30 menit reaksi dihentikan dengan penambahan 100 $\mu 1$ larutan $0,1 \mathrm{M} \mathrm{Na}_{2} \mathrm{CO}_{3}$, lalu absorban dari p-nitrofenol diukur pada panjang gelombang $410 \mathrm{~nm}$ dengan spektrofotometer. Dengan prosedur yang sama dilakukan untuk $10 \mathrm{ppm}$ glukobay sebagai kontrol.

Tabel 1.

Kondisi reaksi uji inhibisi $\alpha$-glukosidase

\begin{tabular}{|l|c|c|c|c|c|c|}
\hline \multirow{2}{*}{ Reagen } & \multicolumn{7}{|c|}{ Volume $(\mu \mathrm{l})$} \\
\cline { 2 - 7 } & Bo & B1 & So & S1 & Ao & A1 \\
\hline Sampel & - & - & 10 & 10 & 10 & 10 \\
\hline DMSO & 10 & 10 & - & - & - & - \\
\hline $\begin{array}{l}\text { Bufer } \\
\text { fosfat }\end{array}$ & 50 & 50 & 50 & 50 & 50 & 50 \\
\hline PNPG & 25 & 25 & 25 & 25 & 25 & 25 \\
\hline Enzim & - & 25 & - & 25 & - & 25 \\
\hline Inkubasi & \multicolumn{7}{|c|}{$37^{\circ} \mathrm{C}, 30$ menit } \\
\hline $\mathrm{Na}_{2} \mathrm{CO}_{3}$ & 100 & 100 & 100 & 100 & 100 & 100 \\
\hline
\end{tabular}

Keterangan: $\mathrm{Bo}=$ kontrol blanko, $\mathrm{B} 1=$ blanko, $\mathrm{So}=$ kontrol sampel, $\mathrm{S} 1=$ sampel, $\mathrm{Ao}=$ kontrol glukobay, $\mathrm{A} 1=$ glukobay Persen inhibisi(\% I) dihitung dengan rumus:

$$
\% \mathrm{I}=\mathrm{A}_{\text {kontrol }}-\mathrm{A}_{\text {sampel }} \mathrm{X} 100 \%
$$$$
\text { Akontrol }
$$ 


\section{HASIL DAN PEMBAHASAN}

Hasil identifikasi sampel yang dilakukan di laboratorium biologi Universitas Riau menunjukkan bahwa sampel merupakan tumbuhan asam jawa (Tamarindus indica Linn) dengan famili Fabaceae (Gambar 1).

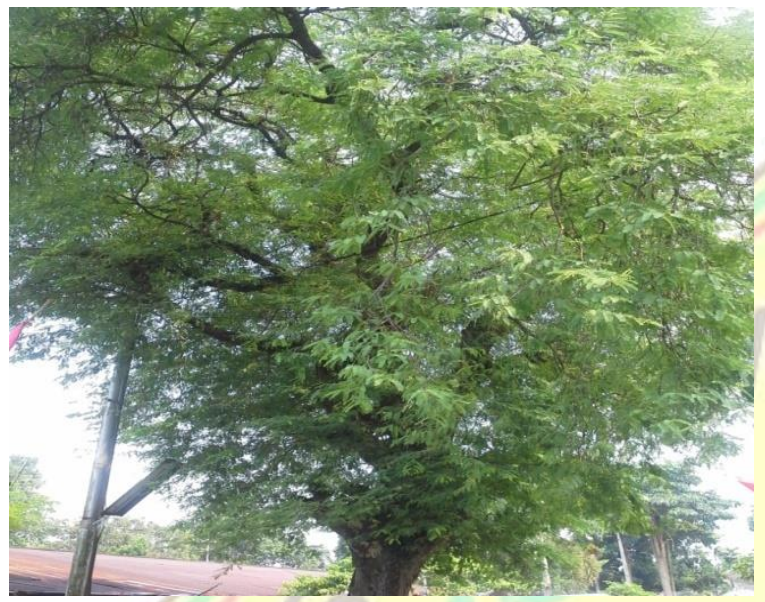

Gambar 1. Tumbuhan Asam Jawa

Sampel kemudian diekstraksi dan difraksinasi dan diperoleh data persen rendemen. Rendemen merupakan presentasi untuk bagian yang dapat diekstrak dari bahan mentah. Besar rendemen hasil ekstraksi $250 \mathrm{~g}$ daun asam jawa dihitung dalam persen rendemen yang dapat dilihat pada tabel 1. Hasil menunjukkan bahwa sebagai berikut fraksi etil asetat memiliki \% rendemen tertinggi yaitu $3,733 \%$. Perbedaan rendemen yang diperoleh dapat disebabkan karena perbedaaan kandungan metabolit sekunder pada daun asam jawa dan jenis pelarut yang berbeda juga dapat mempengaruhi jumlah rendemen yang dihasilkan.

Tabel 2. Rendemen ekstrak daun asam jawa

\begin{tabular}{|c|c|}
\hline Jenis sampel & Rendemen \% \\
\hline Ekstrak $n$-heksan & 1,446 \\
Ekstrak etil asetat & 3,733 \\
Esktraketanol & 1,781 \\
\hline
\end{tabular}

Daun asam jawa yang telah diekstraksi dan difraksinasi kemudian diperiksa kandungan metabolit sekundernya. Hasil menunjukkan bahwa ekstrak etanol mengandung senyawa flavonoid, fenolik dan saponin. Keberadaan senyawa flavonoid, fenolik dan terpenoid pada daun keji beling diduga berperan sebagai inhibitor enzim $\alpha$ glukosidase. Berdasarkan phrmacognosy review yang ditulis Kumar et al (2011), flavonoid dan fenolik berperan dalam menghambat enzim $\alpha$-glukosidase.

Tabel 2.

Hasil pemeriksaan kandungan metabolit sekunder Eksrak etanol daun asam jawa

\begin{tabular}{|c|c|c|}
\hline $\begin{array}{c}\text { Kandungan } \\
\text { Kimia }\end{array}$ & Pereaksi & $\begin{array}{c}\text { Ekstrak } \\
\text { Etanol } \\
\end{array}$ \\
\hline Alkaloid & Mayer & tidak terbentuk \\
\hline Flavonoid & $\begin{array}{l}\text { Logam } \\
\mathrm{Mg}+\mathrm{HClp}\end{array}$ & $\begin{array}{l}\text { terbentuk larutan } \\
\text { merah }(+)\end{array}$ \\
\hline Terpenoid & $\mathrm{LB}$ & Tidak terbentuk \\
\hline Steroid & $\mathrm{LB}$ & larutan merah(-) \\
\hline Fenolik & $\mathrm{FeCl}_{3}$ & Tidak terbentuk \\
\hline Saponin & Air/busa & $\begin{array}{l}\text { larutan. Biru (-) } \\
\text { Terbentuk } \\
\text { larutan biru (+) }\end{array}$ \\
\hline & & $\begin{array}{l}\text { Terbentuk busa } \\
(+)\end{array}$ \\
\hline
\end{tabular}

Ket: LB ( Lieberman-Bouchard)

Untuk mengetahui aktivitas penghambatan senyawa fenolik, flavonoid dan saponin pada ekstrak etanol terhadap $\alpha$ glukosidase pada daun asam jawa, maka dilakukan ekstraksi bertingkat untuk memisahkan senyawa berdasarkan kepolarannya. Hasil uji aktivitas antidiabetes ekstrak etanol terhadap enzim $\alpha$-glukosidase pada konsentrasi 250-1000 ppm menunjukkan bahwa semakin tinggi konsentrasi semakin tinggi pula \% inhibisi. Berdasarkan data tabel 3 diketahui bahwa aktivitas penghambatan (\% Inhibisi) tertinggi pada konsentrasi 1000 ppm kategori lemah yaitu sebesar $20 \%$. Aktivitas ekstrak etanol pada konsentrasi tertinggi 1000 ppm belum dapat menghambat $50 \%$ 
aktivitas enzim sehingga tidak dapat diketahui nilai Inhibition concentration 50\% atau IC50. Suatu ekstrak dikatakan berpotensi memiliki aktivitas biologis pada konsentrasi $\leq 1000 \mathrm{ppm}$.

Tabel 3.

Hasil inhibisi ekstrak etanol dan ekstrak etil asetat terhadap enzim $\alpha$-glukosidase

\begin{tabular}{|cl|}
\hline $\begin{array}{c}\text { Konsentrasi } \\
(\mathrm{ppm})\end{array}$ & $\underline{\underline{\text { Daya Inhibisi (\%) }}}$ \\
\hline 1000 & Ekstrak Etanol \\
500 & 5,06 \\
250 & 2,67 \\
\hline
\end{tabular}

Berdasarkan data tabel 4 menunjukkan bahwa aktivitas glukobay lebih besar dibandingkan aktivitas ekstrak etanol. Pada konsentrasi 10 ppm ppm, glukobay memiliki daya inhibisi sebesar $92,927 \%$ \%. Aktivitas inhibisi berkurang dengan semakin kecilnya konsentrasi. Glukobay adalah obat inhibitor $\alpha$-glukosidase dan digunakan dalam pengobatan penyakit diabetes. Glukobay memiliki senyawa aktif akarbose. Satu tablet glukobay mengandung senyawa akarbose $100 \mathrm{mg}$. Efek inhibisi glukobay lebih besar dibanding ekstrak etanol daun asam jawa.

Tabel 4. Hasil inhibisi Glukobay terhadap $\alpha$ glukosidase

\begin{tabular}{|cc|}
\hline Konsentrasi ppm & $\%$ inhibisi \\
\hline & \\
10 & 92,927 \\
5 & 78,894 \\
1 & 60,384 \\
0,1 & 41,384 \\
\hline
\end{tabular}

Prinsip analis pengujian ini adalah suatu zat yang bertindak sebagai inhibitor akan berikatan dengan enzim $\alpha$-glukosidase sehingga aktivitas enzim dalam menghidrolisis substrat pNPG (p-nitrofenil$\alpha$-D-glukopiranosida) menjadi $p$-nitrofenol yang berwarna kuning akan terhambat. Absorbansi yang diukur berdasarkan jumlah p-nirofenol yang terbentuk. Pengukuran dilakukan dengan alat spektrofotometer pada panjang gelombang $410 \mathrm{~nm}$. Semakin sedikit p-nirofenol yang terbentuk maka semakin kecil nilai absorbansi dan semakin tinggi aktivitas penghambatannya.

\section{KESIMPULAN}

1. Senyawa metabolit sekunder ekstrak etanol adalah senyawa flavonoid, fenolik dan saponin

2. Aktivitas antidiabetes ekstrak etanol daun asam jawa terhadap penghambatan enzim $\alpha$-glukosidase pada konsentrasi 1000 ppm adalah $20,8 \%$

\section{DAFTAR PUSTAKA}

Kumar, S., Narwal, S., Kumar, V., and Prakash, O., 2010, $\alpha$-Glucosidase Inhibitor from plants: A natural approach to treat diabetes, pharmacognosy review, vol 5

Lee, 2007, Inhibitory activity of Euonymus alatus against $\alpha$-glucosidase in vitro and invivo, J.Nutr Re Pract, 1-1. 84-188

Matsumoto, K, et al, 2002, A novel method for the assay of a-glukosidase inhibitory activity using a multi-chanel oxygen sensor, J anal Sci,18:1351-1319

Modak, M, Dixn, P, Londir, J, Ghaskadai, S dan Devasagayam,TPA, 2007, Indian herbs and herbal drugs used for the treatment of diabetes, Journal Clinical Biochemistry Nutrition,40:163-173

Ramchander. T, Rajkumar. D, Ravanfasad. M, Venkateswarlu Goli, Dhanalakshmi.CH, Arjun, 2012, Antidibetic actitivity of Aqueous Methanolic Extracts o leaf of Tamarindus Indica, International Journal of Pharmacognosy and Phytochemical Research 4 (1): 5-7

Soedibyo. M, 1998, Alam Sumber Kesehatan, Manfaat dan Kegunaan, Jakarta: Balai Pustaka 
Sancheti, Sh., Sancheti, Sa., Yum Seo, S., 2009., Chaenomeles Sinenesis: A Potent $\alpha$ and $\beta$-Glucosidase Inhibitor.,
American Journal of Pharmacology and

Toxicology 4(1):8-11., ISSN1557-4962

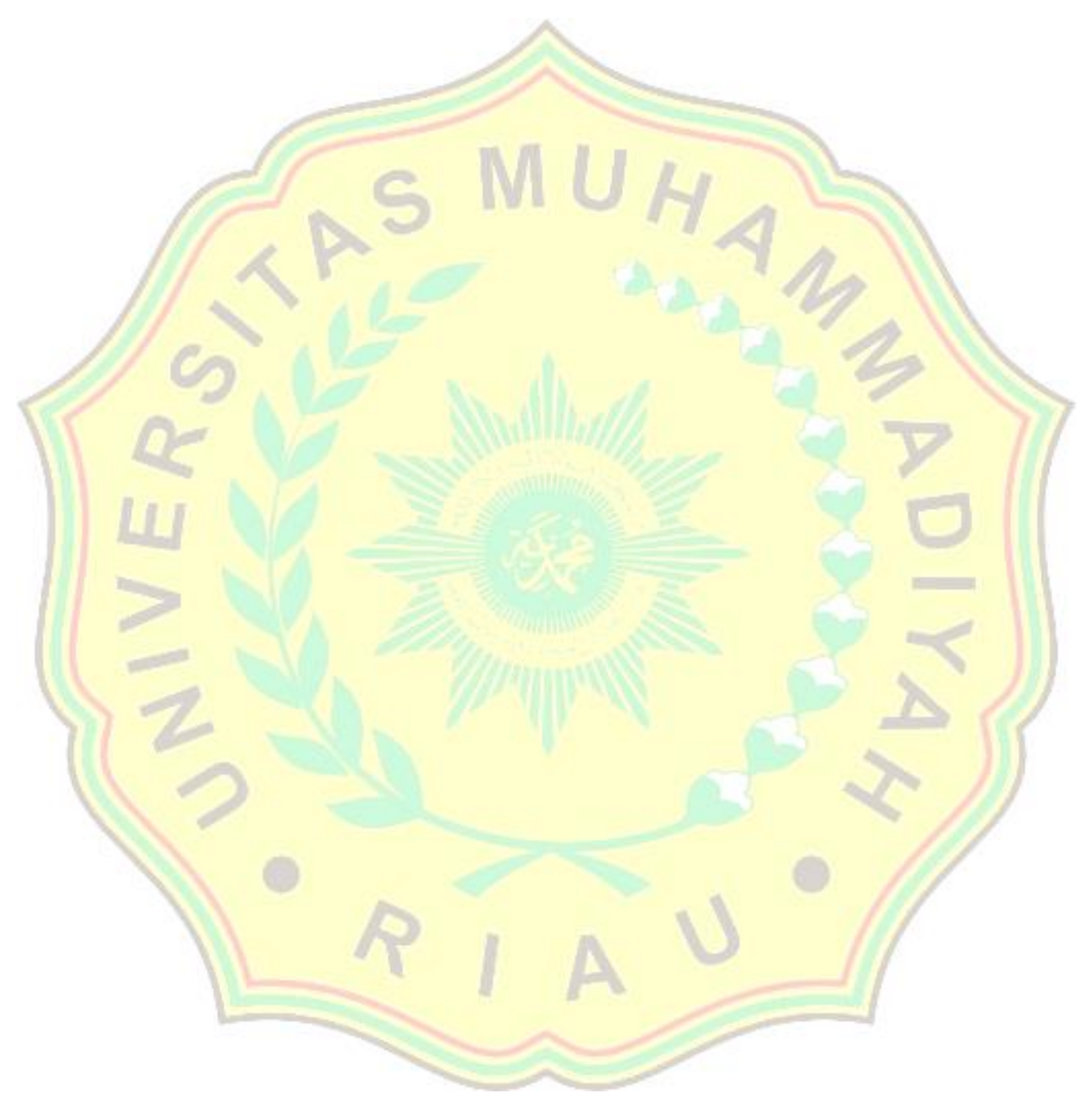

